\title{
Maternal transfer of dechloranes and their distribution among tissues in contaminated ducks
}

\author{
Ping-Fan $\mathrm{Wu}^{\mathrm{a}, \mathrm{b}}$, Lian-Lian $\mathrm{Yu}^{\mathrm{a}, \mathrm{b}}$, Long $\mathrm{Li}^{\mathrm{a}}$, Yun Zhang ${ }^{\mathrm{a}}$, Xing-Hong $\mathrm{Li}^{\mathrm{b},{ }^{*}}$

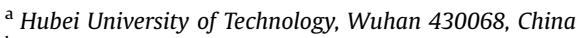 \\ b State Key Laboratory of Environmental Chemistry and Ecotoxicology, Research Center of Eco-Environmental Sciences, Chinese Academy of Sciences, PO Box \\ 2871, 18 Shuangqing Road, Haidian District, Beijing 100085, China
}

\section{H I G H L I G H T S}

- Relatively serious contamination of DP was found in the e-waste recycling sites, Taizhou.

- Lipid pool, liver sequestration and blood-barrier affect tissue distribution of DP and its analogues.

- The maternal transfer extent of Dec 602 was over one.

- The stereo-selective accumulation of DP occurs among duck tissues.

- The monodechlorinated products in duck likely originated from the exterior environment.

\section{A R T I C L E I N F O}

\section{Article history:}

Received 1 September 2015

Received in revised form

29 October 2015

Accepted 3 November 2015

Available online 30 November 2015

Handling Editor: Gang Yu

\section{Keywords:}

DP and DP-like compound

Tissue-specific distribution

Maternal transfer

Duck

\begin{abstract}
A B S T R A C T
The tissue concentrations of dechlorane plus and its analogues were determined in ducks collected from several e-waste recycling villages of Taizhou, China. Compared with the published literature, the relatively high concentrations of these compounds were detected in ducks, indicating serious DP contamination. Since both the duck meat and eggs were important components for diet, this result reminded us of keeping a watchful eye on human dietary exposure to DP and its analogues in this study area. The wetweight concentrations of DP and its analogues were significantly related to tissue lipid content $(p<0.05)$, indicating that the lipid pools predominantly impacted the distribution of DPs in ducks. On the basis of lipid adjustment, the significantly lower levels in brain than those in liver and blood, displayed the occurrence of liver sequestration and blood-brain barrier to DP and its analogues in the duck $(p<0.05)$. The maternal transfer of DP and Mirex was not obviously limited, and the transferring extent of Dec 602 was over one. The stereo-selected accumulation of two DP isomers occurred among tissues with preference to syn-DP in blood, and to anti-DP in brain. The values of lipid-adjusted monodechlorinated products mainly originated from the exterior environment in ducks.
\end{abstract}

(C) 2015 Elsevier Ltd. All rights reserved.

\section{Introduction}

Dechlorane plus (DP) is one kind of organic halogenated flame retardants. Since 1960s, DP was produced as a replacement of Mirex. Due to its excellent thermal stability, flame retardancy and low smoke generation, there has been a widespread application of DP in many materials. Currently the annual production of technical DP can be as high as 10 million pounds (Yu et al., 2010), and it has been classified as a high production volume chemical (HPV) in the

\footnotetext{
* Corresponding author.

E-mail address: lxhzpb@rcees.ac.cn (X.-H. Li).
}

United States, also listed on Canada's Domestic Substances Lists (Sverko et al., 2010). Recently, DP is also considered as a possible replacement for decabromodiphenyl ether (Commission, 2011), likely resulting in its more application in the future.

DP has been detected in various environmental matrixes, including the atmosphere (Salamova and Hites, 2011; Yu et al., 2011) surface water (Moller et al., 2010; Wu et al., 2010), soil (Wang et al., 2010a,b,c; Yu et al., 2010) and sediments (Shen et al., 2011; Tomy et al., 2007), also tree bark (Qiu and Hites, 2008). Some studies showed that DP can be well accumulated in wildlife (Sun et al., 2012; Zhang et al., 2011) and human tissue (Ben et al., 2013, 2014; Ren et al., 2009; Siddique et al., 2012; Zheng et al., 2010), and be easily biomagnified across the trophic levels (Sun 
et al., 2012; Tomy et al., 2007; Zhang et al., 2011). The occurrence of DP analogues, for instance, $\mathrm{Cl}_{10}$-DP, $\mathrm{Cl}_{11}$-DP, Mirex, Dec 602, Dec 603 and Dec 604 were also reported in both abiotic and biotic samples (Chen et al., 2011; Guerra et al., 2011; Jia et al., 2011; Li et al., 2014; Peng et al., 2012; Shen et al., 2011, 2009; Sverko et al., 2010; Wang et al., 2010a,b,c; Yang et al., 2011a,b). All these studies imply the potential risk of DP and its analogues impose on the environment and human health.

Tissue distribution plays an important role in toxicology, which can help us understand the migration and transformation among tissues, thus to find the target organ needing further research on the toxic effect of different pollutants (Peng et al., 2012). So far, there were several research papers about tissue distribution of DP in fish (Peng et al., 2012; Zhang et al., 2011), birds (Sun et al., 2012) and frogs (Li et al., 2014). These studies revealed the speciesspecific migration and transformation pattern of DP among tissues, such as the blood-brain barrier, retention in liver and maternal transfer efficiency. However, there still lies an obvious data gap for the tissue distribution of domestic fowls, which are good indicators of ambient persistent organic pollutants (POPs) levels, considering the intensive contact of the fowls with the environment (Luo et al., 2009). Our aim of this study is to detect the tissue concentrations of DP and its analogues products (including monodechlorinated DP, Mirex and Dec 602, Dec 603 and Dec 604) in contaminated ducks collected from some e-waste recycling villages, and provide a further discussion about the liver sequestration, blood-brain barrier, maternal transfer and stereo-selective bioaccumulation of DP.

\section{Materials and methods}

\subsection{Chemicals}

Stock solutions of syn-DP $\left(100 \mu \mathrm{g} \mathrm{mL}^{-1}\right)$, anti-DP $\left(100 \mu \mathrm{g} \mathrm{mL}^{-1}\right)$, ${ }^{13} \mathrm{C}_{10}$ syn-DP $(100 \mu \mathrm{g} \mathrm{mL}-1),{ }^{13} \mathrm{C}_{10}$ anti-DP $(100 \mu \mathrm{g} \mathrm{mL}-1)$ and ${ }^{13} \mathrm{C}_{12}$ PCB-208 (40 $\mu \mathrm{g} \mathrm{mL}^{-1}$ ) were obtained from Cambridge isotope laboratories Inc. (Massachusetts, USA). Stock solutions of anti- $\mathrm{Cl}_{10^{-}}$ DP $\left(50 \mu \mathrm{g} \mathrm{mL}^{-1}\right)$, anti-Cl 11 -DP $\left(50 \mu \mathrm{g} \mathrm{mL}^{-1}\right)$ and Mirex $\left(100 \mu \mathrm{g} \mathrm{mL}^{-1}\right)$ were purchased from Wellington Laboratories Inc. (Guelph, ON, Canada). Dec 602, Dec 603 and Dec 604 were purchased from Toronto Research Chemical Inc. (North York, ON, Canada). Except for $n$-hexane and dichloromethane were pesticide grade, other solvents including methanol, ethanol, methyl tertiary butyl ether and isopropanol were LC grade. Dichloromethane and isopropanol were obtained from J.T. Baker (Deventer, The Netherlands); n-hexane, methanol and ethanol were supplied by Fisher Scientific (Pittsburgh, USA); methyl tertiary butyl ether was obtained from Tedia (Fairfield, USA). $\mathrm{H}_{2} \mathrm{SO}_{4}$ (98\%) was supplied by Sinopharm Chemical Reagent Co. Ltd (Beijing, China). Sodium sulfate anhydrous (granular, purity $>99.5 \%$ ) was from Jinke Refined Chemical institutes (Tianjin, China). Silica gel (60-100 mesh) was purchased from Merck (Germany).

\subsection{Sample collection}

Taizhou City is located at the middle of the coastal area of Zhejiang Province and in the south tip of the Shanghai Economic Zone in China ( $28^{\circ} \mathrm{N}$ latitude and $122^{\circ} \mathrm{E}$ longitude). Dismantling operations for e-wastes in this area have been ongoing for approximately 30 years.

Five villages in Taizhou city, including HMQ ZG, TS, NW, and LH, were selected as the study sites. Both of HMQ and ZG are typical recycling sites for the obsolete transformers, and both of TS and NW are traditional e-waste dismantling sites for printed circuit boards and cable wires, while LH village was without e-waste recycling operation. Nine ducks (Anas platyrhynchos domesticus), fed about 10-12 months, were selected randomly in nine duck flocks (generally $>50$ ducks as a flock) from the five villages mentioned above in July 2012. One duck was collected from LH (a low contamination site), and two, respectively, from HMQ ZG, TS and NW (high contamination sites). The collected ducks were brought to the laboratory and blood samples (about $20 \mathrm{~mL}$ ) were taken following euthanasia. Then, the liver, pectoral muscle, abdominal adipose, brain and egg tissues were excised. After being homogenized in a tissue homogenizer, various tissues except for blood were freeze-dried, and then kept frozen at $-20{ }^{\circ} \mathrm{C}$ until analysis.

\subsection{Sample extraction, clean-up, and analysis}

The extraction, clean-up, and analysis of DP isomers and its analogs in blood and tissue samples were performed as described in our previous study with minor modification (Ben et al., 2014). In brief, after spiking of recovery surrogate ${ }^{13} \mathrm{C}_{10}$ syn-DP and ${ }^{13} \mathrm{C}_{10}$ anti-DP, tissue samples were homogenized, then ultrasonically extracted 3 times ( 7 min per time) with methyl tertiary butyl ether: hexane: dichloromethane, 1: 1: $1(\mathrm{v}: \mathrm{v}: \mathrm{v})$. An aliquot of the extract was used for the determination of lipid by gravimetry. The remaining extract was subjected to a chromatography column (30 $\mathrm{cm} \times 10 \mathrm{~mm}$ ID) containing $8.0 \mathrm{~g}$ sulfuric acid silica (30\% acid by weight) and $2.5 \mathrm{~g}$ of anhydrous sodium sulphate on top to purify. The injection internal standard $\left({ }^{13} \mathrm{C}_{12}\right.$-PCB-208) was added prior to the GC/NCI-MS analysis.

The quantification of DP and its analogues was performed using an Agilent 6890 GC, coupled with 5973 MSD. The MS analyses were performed in an electron capture negative ionization (ECNI) mode. The separation was performed using a fused silica capillary column (RTX-1614, $30 \mathrm{~m} \times 0.25 \mathrm{~mm}$ ID and $0.1 \mu \mathrm{m}$ film thickness; J\&W Scientific, Folsom, CA, USA). The carrier gas used was helium, with a flow rate of $1.0 \mathrm{~mL} \mathrm{~min}{ }^{-1}$, and methane was used as the reaction gas. The GC oven temperature was programmed as follows: the initial temperature was maintained at $100{ }^{\circ} \mathrm{C}$ for $2 \mathrm{~min}$, then increased to $250{ }^{\circ} \mathrm{C}$ at a rate of $25{ }^{\circ} \mathrm{C} \mathrm{min}^{-1}$, followed by a $1.5{ }^{\circ} \mathrm{C} \mathrm{min}{ }^{-1}$ ascent to $260{ }^{\circ} \mathrm{C}$, and finally, the temperature was increased at a rate of $25^{\circ} \mathrm{C} \mathrm{min}{ }^{-1}$ to achieve the final temperature level of $315^{\circ} \mathrm{C}$, maintained for $7 \mathrm{~min}$. The injector, transfer line, and ion source temperatures were 250,280 , and $150{ }^{\circ} \mathrm{C}$, respectively. The ion fragments were monitored as follows: $\mathrm{m} / \mathrm{z} 617.7$ and 619.7 for anti- $\mathrm{Cl}_{11}$-DP and syn- $\mathrm{Cl}_{11}-\mathrm{DP}, \mathrm{m} / z 583.7$ and 585.7 for anti- $\mathrm{Cl}_{10^{-}}$ DP, $m / z 651.7$ and 653.7 for syn-DP and anti-DP, $m / z 403.7$ and 401.7 for Mirex, $m / z 613.6$ and 611.6 for Dec 602, $m / z 637.7$ and 635.7 for Dec 603, $\mathrm{m} / z 79$ and 81 for Dec 604, $\mathrm{m} / z 661.7$ and 663.7 for ${ }^{13} \mathrm{C}_{10}$ labeled syn-DP and anti-DP, $m / z 510$ and 508 for ${ }^{13} \mathrm{C}_{12}$-labeled CB209 and $m / z 476$ and 478 for ${ }^{13} \mathrm{C}_{10}$ labeled PCB-208. syn-Cl $\mathrm{Cl}_{11}$-DP is quantified by the relative response factor of anti-Cl ${ }_{11} \mathrm{DP}$.

\subsection{Quality control}

Laboratory procedure blanks were analyzed for every set of 11 samples. No target compound was found in the blanks. The recoveries of DP and its analogues were estimated by the spiked internal standards, the recoveries of the internal standards were 62.1-117\% for ${ }^{13} \mathrm{C}_{10}$ syn-DP, $64.6 \%-113 \%$ for ${ }^{13} \mathrm{C}_{10}$ anti-DP and 73.9-109\% for ${ }^{13} \mathrm{C}_{12}$ CB-209. The limits of detection (LODs) were defined as the concentration of target compounds in sample producing a peak in chromatogram with a signal-to-noise $(\mathrm{S} / \mathrm{N})$ ratio of 3 , and LODs ranged from 13 (egg) to 181 (blood), 25 to 270, 11 to 111 , 18 to $309,27-190 \mathrm{pg} \mathrm{g}^{-1}$ lw for syn-DP, anti-DP, anti-Cl ${ }_{11}-\mathrm{DP}$, Mirex and Dec 602, respectively. All reported concentrations were corrected by surrogate recovery. 


\subsection{Data analysis}

All the statistical analyses were performed using SPSS 18.0 statistical software. Spearman correlation analysis was employed to assess the relevance between the tissue lipid contents and the wetweight concentrations of DP and its analogues. Two-RelatedSample Tests were employed to compare the tissue concentrations. The fractional abundance of anti-DP $\left(f_{a n t i}\right)$ was compared by one-way Anova. The significance for all analysis was set at $p<0.05$.

\section{Results and discussion}

\subsection{Residue levels of DP and its analogues}

In this study, DP (syn-DP and anti-DP) and its related analogues (anti-Cl $\mathrm{Cl}_{10}$-DP, syn- $\mathrm{Cl}_{11}$-DP and anti-Cl $\mathrm{Cl}_{11}$-DP, Mirex, Dec 602, Dec 603 and Dec 604), were determined in five compartments, including whole blood, liver, muscle, fat and brain tissue, from nine domestic ducks collected in Taizhou, China. The target compounds from the matched eggs $(n=6)$ were also determined in order to examine their maternal transfer. Levels of DP and its related analogues were shown in Table 1 as lipid weight (lw).

To date, some studies have been conducted to investigate the tissue levels of DP in birds and their eggs. Similar DP levels were found in water birds from another e-waste recycling region in China, with the DP concentrations ranging from nd- $610 \mathrm{ng} \mathrm{g}^{-1} \mathrm{lw}$ in the muscle (Zhang et al., 2011). The DP levels were comparable to those observed in herring gulls eggs from the Great Lakes region with the DP production source ( $<15 \mathrm{ng} \mathrm{g}^{-1} \mathrm{ww}$ ) (Gauthier and Letcher, 2009), and in terrestrial passerine bird species from Pearl River Delta of China (PRD), a region with burgeoning electronic/ electrical manufacturing industries and intensive e-waste recycling activities (3.9-930 $\mathrm{ng} \mathrm{g}^{-1} \mathrm{lw}$ in muscle; 7.0-1300 $\mathrm{ng} \mathrm{g}^{-1} \mathrm{lw}$ in liver) (Sun et al., 2012). The comparison indicated relatively serious DP pollution in this study region. However, the DP level in homeproduced eggs from other three e-waste recycling sites in South China, varied from hundreds to thousands ng $\mathrm{g}^{-1} \mathrm{lw}$ (Zheng et al., 2012), which was two to three orders of magnitude higher than our study. In short, these findings remind us of paying close attention to dietary contamination of DP in e-waste recycling environment, in view that both the duck meat and egg were important components for diet.

There is scarce literature reported the accumulation of dechlorination products of DP in biota. To our knowledge, anti- $\mathrm{Cl}_{10}$-DP was only found in biota in the limited published literature (Guerra et al., 2011; Zhang et al., 2011). However, both syn-Cl ${ }_{11}$-DP and anti$\mathrm{Cl}_{11}$-DP were detected consistently in various biotas. For instance, the concentration of syn- $\mathrm{Cl}_{11}$-DP and anti- $\mathrm{Cl}_{11}$-DP in liver gathered from terrestrial passerine bird species from PRD of China was nd$41 \mathrm{ng} \mathrm{g}^{-1} \mathrm{lw}$ and nd-7.5 $\mathrm{ng} \mathrm{g}^{-1} \mathrm{lw}$, respectively, and in muscle was nd-6.5 $\mathrm{ng} \mathrm{g}^{-1} \mathrm{lw}$ and nd-7.6 $\mathrm{ng} \mathrm{g}^{-1} \mathrm{lw}$, respectively (Sun et al., 2012). The levels of anti- $\mathrm{Cl}_{11}$-DP were nd to $4.7 \mathrm{ng} \mathrm{g}^{-1} \mathrm{ww}$ in chicken tissues collected from Qingyuan county of Guangdong province (Zheng et al., 2014), and nd-1.84 $\mathrm{ng} \mathrm{g}^{-1} \mathrm{lw}$ in peregrine falcon eggs collected from Canada and Spain (Guerra et al., 2011). In this study, anti-Cl $\mathrm{Cl}_{10}$-DP was not found and similar concentrations of syn- $\mathrm{Cl}_{11}$-DP/anti-Cl $\mathrm{Cl}_{11}$-DP were detected when compared with the Great Lakes region and PRD (industry district) in China. The results from our study and references showed that anti- $\mathrm{Cl}_{10}$-DP may not be prone to be accumulated in biota, which was contrary to monodechlorinated DP.

In view of other DP-like compounds, both of Mirex and Dec 602 were detected in most of samples, whereas both of Dec 603 and Dec 604 were not found in all samples. The median concentrations of Mirex and Dec 602 in Chinese sturgeon eggs from the Yangze river, was $0.32 \mathrm{ng} \mathrm{g}^{-1} \mathrm{lw}$ and $0.02 \mathrm{ng} \mathrm{g}^{-1} \mathrm{lw}$ (recalculated on the basis of the lipid content as 35\%), respectively (Peng et al., 2012). Guerra et al. (2011) reported the geometric mean value in peregrine falcon eggs collected from the Canadian Great Lakes, was $641 \mathrm{ng} \mathrm{g}^{-1}$ $\mathrm{lw}$ for Mirex and $73.2 \mathrm{ng} \mathrm{g}^{-1} \mathrm{lw}$ for Dec 602, respectively. The level of Mirex and Dec 602 in our study were much higher than those in Chinese sturgeon (representing the background level). Although the levels of Mirex and Dec 602 were much lower than those in peregrine falcon eggs collected from the Canadian Great Lakes, their existence in human diet (muscle and egg) should not be ignored as for their relatively higher potential of bioaccumulation (Peng et al., 2012; Shen et al., 2011).

There existed great regional variance on the DP concentration in duck tissues. The mean concentration of DP in duck muscle was $6.28 \mathrm{ng} \mathrm{g}^{-1} \mathrm{lw}, 6.66 \mathrm{ng} \mathrm{g}^{-1} \mathrm{lw}, 90.2 \mathrm{ng} \mathrm{g}^{-1} \mathrm{lw}, 291 \mathrm{ng} \mathrm{g}^{-1} \mathrm{lw}$ and $1.44 \mathrm{ng} \mathrm{g}^{-1} \mathrm{lw}$ from HMQ ZG, TS, NW and LH, respectively. E-waste recycling operations were not allowable in $\mathrm{LH}$, resulting in its lowest level. Both NW and TS were two typical villages recycling a large amount of DP-containing electric/electrical equipment such as electronic wire/cable and printed circuit boards, whereas both HMQ and ZG had even been two typical transformers/capacitors (containing PCBs) recycling villages. The type of e-waste products recycled may be one of important factors impacted the

Table 1

Levels of dechloranes in tissues of duck collected from the five sites in Taizhou City, Zhejiang Province, Eastern China (ng $\mathrm{g}^{-1}$ lw).

\begin{tabular}{|c|c|c|c|c|c|c|}
\hline & Blood & Brain & Liver & Fat & Muscle & Egg \\
\hline \multicolumn{7}{|c|}{ Contamination sites ${ }^{\mathrm{a}}$} \\
\hline Dec602 & $0.27\left(\mathrm{nd}^{\mathrm{b}}-1.04\right)$ & $0.24(\mathrm{nd}-1.97)$ & $0.48(0.12-1.20)$ & $1.21(0.55-5.49)$ & $1.00(0.11-2.07)$ & $0.60(0.11-1.85)$ \\
\hline Mirex & $1.49(0.25-9.03)$ & $0.53(\mathrm{nd}-2.53)$ & $2.61(0.79-5.72)$ & $5.54(2.56-8.18)$ & $4.94(1.90-8.71)$ & $0.88(0.27-7.85)$ \\
\hline syn- $\mathrm{Cl}_{11}-\mathrm{DP}$ & $0.19(\mathrm{nd}-0.92)$ & $-{ }^{c}(\mathrm{nd}-0.10)$ & $0.04($ nd -13.0$)$ & $0.72($ nd- -2.01$)$ & $1.23(\mathrm{nd}-4.85)$ & $0.04(0.01-0.08)$ \\
\hline syn-DP & $2.48(0.36-23.5)$ & $0.36(0.09-2.72)$ & $4.44(0.42-439)$ & $16.9(0.55-51.2)$ & $9.11(1.46-90.0)$ & $1.94(1.12-4.53)$ \\
\hline anti- $\mathrm{Cl}_{11}-\mathrm{DP}$ & $0.45(\mathrm{nd}-1.73)$ & $-(\mathrm{nd}-0.59)$ & $0.23(\mathrm{nd}-28.0)$ & $1.26(0.11-4.91)$ & 0.41 (nd-13.8) & $0.10(0.03-0.26)$ \\
\hline anti-DP & $4.57(1.22-29.1)$ & $3.05(0.41-9.26)$ & $13.1(2.60-783)$ & $43.4(1.85-96.4)$ & $22.1(4.03-210)$ & $3.19(2.28-12.1)$ \\
\hline$\sum D P$ & $6.97(1.58-52.6)$ & $3.58(0.50-12.0)$ & $17.8(3.32-1221)$ & $60.3(2.40-148)$ & $31.1(5.81-294)$ & $5.13(3.40-16.7)$ \\
\hline \multicolumn{7}{|c|}{ Low contamination site } \\
\hline Dec602 & 0.07 & 0.48 & 0.13 & 0.15 & 0.08 & 0.32 \\
\hline Mirex & 0.17 & 0.21 & 0.75 & 1.44 & 1.01 & 0.79 \\
\hline syn- $\mathrm{Cl}_{11}-\mathrm{DP}$ & 0.12 & nd & nd & nd & nd & 0.01 \\
\hline syn-DP & 0.93 & 0.32 & 0.51 & 0.29 & 0.24 & 0.73 \\
\hline anti- $\mathrm{Cl}_{11}-\mathrm{DP}$ & 0.18 & 0.11 & nd & 0.04 & nd & 0.01 \\
\hline anti-DP & 2.20 & 1.80 & 1.38 & 0.88 & 1.21 & 1.48 \\
\hline$\sum \mathrm{DP}$ & 3.13 & 2.11 & 1.89 & 1.16 & 1.44 & 2.21 \\
\hline
\end{tabular}

a Median and range.

b nd: not detected.

c -no data. 
contamination situation of DP in these study sites.

\subsection{Characteristics of tissue distribution}

\subsubsection{Lipid-dependent tissue distribution}

Spearman correlation analysis was employed to assess the relevance between the tissue lipid contents and the wet-weight concentrations of DP and its analogues. There was a significant correlation between the total DP concentration and the tissue lipid content in ducks $(p<0.001)$. Similarly, significant correlation was found for DP-like compounds $(p<0.001$ for Dec 602, Mirex, and anti-Cl $\mathrm{Cl}_{11}$-DP, $p<0.006$ for syn- $\mathrm{Cl}_{11}$-DP). That significant correlation indicated that lipid might play a crucial role in tissue distribution of DP and its analogues. This result was consistent with the tissue distribution of DP in chicken (Zheng et al., 2014), in Chinese sturgeons (Peng et al., 2012) and in European eels (Suhring et al., 2015).

\subsubsection{Liver sequestration}

As described in Section 2.1, although lipid pool was a major factor affected the tissue distribution of DP and its analogues, it was not the unique factor. The liver sequestration of DP has been found in the northern snakehead and mud carp, with the preferential distribution of DP in liver compared to muscle and brain tissues (Zhang et al., 2011). Peng et al. (2012) also reported that the lipidnormalized concentrations of dechloranes in liver were all higher than in adipose tissue by 1.7 fold for Mirex to 4.9 fold for Dec 602, showing the hepatic sequestration of dechloranes in Chinese sturgeons. In this study, liver/blood ratio together with the liver/muscle ratio and liver/fat ratio was used to explore the liver sequestration of DP, Mirex and Dec 602 in ducks, and the corresponding results of median/mean ratio was listed in Table 2.

In Table 2, the liver/blood concentration ratio (median/mean value) was more than one to DP, Mirex and Dec 602, but their liver/ fat concentration ratio or liver/muscle concentration ratios showed closer to one or less than one. Fat or muscle tissue was generally considered as the final sink of hydrophobic compounds in biota, and the pollutants accumulated in fat or muscle may undergo more biological process such as absorption, distribution and metabolism. Different from fat and muscle, the liver tissue is the central compartment with abundant blood perfusion. Therefore, the liver/ blood concentration ratio may reflect the occurrence of liver sequestration more than the liver/muscle concentration ratio or liver/fat concentration ratio. Although the dominant liver sequestration of DP was not found when compared to muscle as reported by Zhang et al. (2011) or fat as reported by Peng et al. (2012), the significantly higher level in liver than that in blood demonstrated the occurrence of liver sequestration in ducks (Nonparametric TwoRelated Samples Tests, $p<0.05$ ).

\subsubsection{Blood-brain barrier}

Previous studies have shown that blood-brain barrier can effectively prevent a variety of (POPs) into the brain tissue. For example, compared to brain tissue, preferential enrichment of some persistent organic pollutants (POPs) in liver tissue was found, such as PBDEs in birds of prey (Voorspoels et al., 2006) and in fowls
(Yang et al., 2011a,b), PCDD/Fs in wildlife (Wan et al., 2006), PCBs and OCPs in fur seals(Wang et al., 2010a,b,c). For DP and its analogues, Li et al. (2014) reported that DP and DP-like compounds (including DP, Mirex, Dec 602 and anti-Cl ${ }_{11}$-DP) was more prone to be accumulated in liver compared with brain tissue in frogs. Zhang et al. (2011a), (2011b) found the syn-DP and anti-Cl ${ }_{11}$-DP were richer in liver when compared to brain, but the result of anti-DP in fish was vice versa.

In this study, all of DP and its analogues were detected in the brain tissues of ducks, indicating the potential of these compounds breaking through the blood-brain barrier. However, on the lipidadjusted basis, the median blood/brain concentration ratios of DP and its analogues ranges from 1.3 for Mirex to 5.1 for syn-DP, and the liver/brain concentration ratios varied from 3.2 for Mirex to 11 for syn-DP, respectively (Table 2). The lipid-normalized concentrations in brain tissues were significantly lower than those in blood and liver tissues (Nonparametric Two-Related Samples Tests, $p<0.05$ ), declaring that the protective blood-brain barrier narrows the passage of these compounds into the brain. The result in the present study was similar to the distribution of DP and its analogues in frogs reported by Li et al. (2014), but was inconsistent with the distribution of anti-DP in contaminated fish reported by Zhang et al. (2011a), (2011b). The different blood-brain (liver-brain) accumulation characteristics among ducks, frogs and fish likely implied the species-specific brain uptake of DP in biota.

The blood-brain barrier (BBB) is an important defense mechanism for biota, which could restrict diffusion of large or hydrophilic molecules into the brain (Barrier and Peterson, 2010). Yang et al. (2011a), (2011b) found the great hinder of blood-brain barrier to BDE-209, ascribing to its higher molecular weight. Similar to BDE209, since DP has the large molecular mass weight and high Kow, the structural-dependent properties may be one of the important factors limiting the brain uptake to these compounds in the duck.

\subsubsection{Maternal transfer}

The detection of DP and DP-like compounds in the duck eggs indicated their maternal transfer and potential exposure risk to duck reproduction and human health through diet ingestion. Lipophilic organic chemicals are transferred to eggs along with yolk proteins which are formed in the liver of the mother in oviparous organisms (Russell et al., 1999), so that the ratios of lipid-adjusted egg concentration to lipid-adjusted maternal liver concentration (E/L ratios) (Wu et al., 2009) were calculated to assess the extent of maternal transfer to egg in this study. The median/mean of $\mathrm{E} / \mathrm{L}$ ratios in ducks were listed in Table 2.

Wu et al. (2013) found the existence of species-special maternal transfer in fish. The mean $\mathrm{E} / \mathrm{L}$ ratio was 0.03 and 0.03 in northern snakehead, and 0.26 and 0.25 in Crucian carp, respectively, for synDP and anti-DP. Nevertheless, the ratio in Chinese sturgeon was 1.3 and 1.4 (recalculated on the basis of lipid content), respectively (Peng et al., 2012; Wu et al., 2013). In this study, the median E/L ratios for DP isomers were higher than those in Crucian carp, and lower than those in Chinese sturgeon. The lipid-normalized DP concentrations in duck eggs were insignificantly different from those in liver tissues (Nonparametric Two-Related Samples Tests,

Table 2

Lipid-adjusted concentration ratio of compounds among duck tissues (median/mean value).

\begin{tabular}{|c|c|c|c|c|c|c|}
\hline & Liver/blood & Liver/Fat & Liver/Muscle & Blood/Brain & Liver/Brain & Egg/Liver \\
\hline Dec602 & $2.0 / 2.7$ & $0.8 / 0.6$ & $0.7 / 0.7$ & $1.6 / 2.8$ & $4.6 / 4.1$ & $1.47 / 1.85$ \\
\hline Mirex & $2.1 / 3.5$ & $0.7 / 0.7$ & $0.7 / 0.7$ & $1.3 / 2.8$ & $3.2 / 4.6$ & $0.69 / 0.72$ \\
\hline syn-DP & $1.7 / 5.5$ & $1.1 / 2.0$ & $0.6 / 1.3$ & $5.1 / 6.3$ & $11 / 32$ & $0.82 / 1.35$ \\
\hline anti-DP & $2.4 / 8.6$ & $1.2 / 1.9$ & $0.7 / 1.1$ & $2.9 / 2.5$ & $7.0 / 17$ & $0.72 / 0.71$ \\
\hline$\sum \mathrm{DP}$ & $2.2 / 7.3$ & $1.2 / 1.9$ & $0.6 / 1.2$ & $3.2 / 3.2$ & $7.6 / 21$ & $0.76 / 0.81$ \\
\hline
\end{tabular}


$p>0.05)$. Similar to DP, the median $\mathrm{E} / \mathrm{L}$ ratio of Mirex was 0.69, which was not significantly different from one $(p>0.05)$. The results indicated little barrier to DP and Mirex during the process of maternal transfer. However, Dec 602 exhibited some difference from DP and Mirex. The median E/L ratios for Dec 602 showed 1.47, ranging from 0.96 to 3.41 , implying the possibility of enhanced maternal transfer for Dec 602. It was noticed that the egg samples sizes $(n=6)$ in this study were limited and the results need be assured further.

\subsection{Isomeric profiles of DP in tissues}

Isomeric profiles of DP in different tissues were examined by the fraction of DP, defined as the concentration of anti-DP divided by the total DP concentration. Fig. 1 showed the value of $f_{\text {anti }}$ in different tissues in ducks. The mean value of $f_{\text {anti }}$ in blood, brain, fat, liver, muscle and egg were $0.65,0.83,0.70,0.73,0.72$, and 0.67 , respectively, with the highest value in brain, and the lowest in blood. The difference of $f_{a n t i}$ value among tissues of ducks were analyzed by one-way Anova. The result showed that the $f_{a n t i}$ value of blood was significantly lower than those of other tissues with the except of egg tissue $(p<0.05)$, implying the prior stereo-selective accumulation of syn-DP in blood. It was also found that the $f_{\text {anti }}$ value of brain tissue was significantly higher than those in other tissues $(p<0.05)$, indicating the preferential stereo-selective accumulation of anti-DP in brain. Sühring et al. (2015) reported the preferred distribution of syn-DP into gonads and egg of eels during maturation. Although the $f_{\text {anti }}$ value was not significantly different between muscle and eggs in this study $(p>0.05)$, it showed the higher value in the muscle compared with the eggs. Overall, the occurrence of stereo-selective accumulation of DP isomers among tissues warrants their different exposure risk to organs in biota.

Due to the trans-spatial structure of anti-DP, anti-DP should undergo higher spatial resistance than syn-DP when penetrated the blood-brain barrier, resulting in more accumulation of syn-DP compared to anti-DP. However, it appeared that the structuraldependent theory might not support our result, where anti-DP was prone to accumulate in brain tissue compared to syn-DP. Sverko et al. (2008) reported that two isomers of DP had different

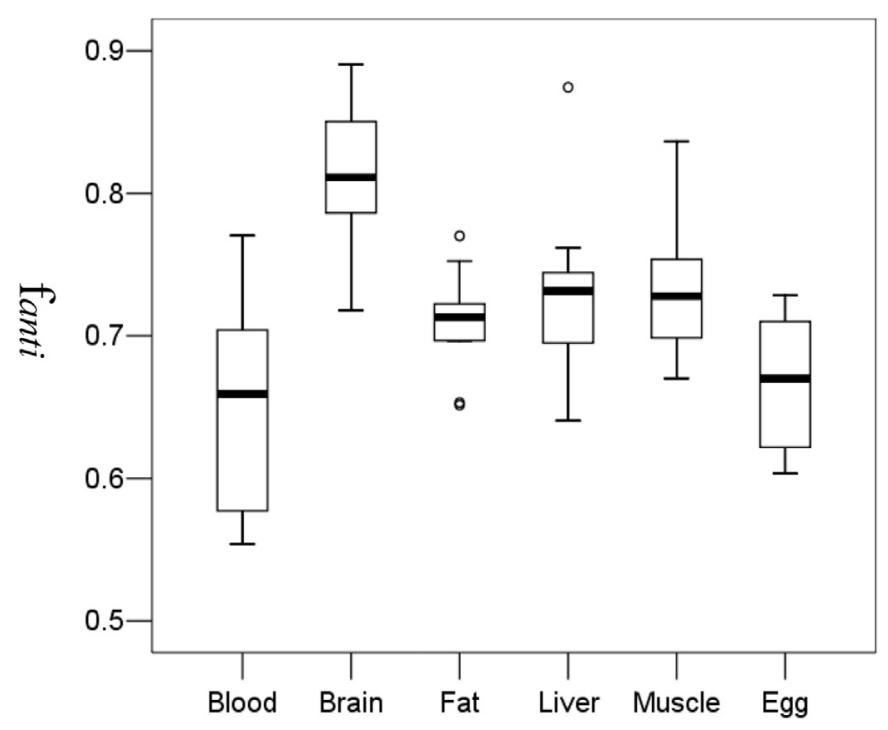

Fig. 1. The value of $f_{\text {anti }}$ in different tissues for duck. Box plots are defined as follows: center line, median; box plot edges, the 25th and 75th percentiles; whiskers, range of data values; circle, outliers.
Table 3

Mean ratio value of monodechlorinated products levels against DP levels in four tissues in ducks.

\begin{tabular}{lllll}
\hline & Liver & Muscle & Blood & Fat \\
\hline anti-Cl ${ }_{11}$-DP/anti-DP & 0.034 & 0.041 & 0.070 & 0.060 \\
syn-Cl ${ }_{11}$-DP/syn-DP & 0.029 & 0.051 & 0.069 & 0.039 \\
\hline
\end{tabular}

aqueous solubility, at $207 \mathrm{ng} \mathrm{L}^{-1}$ and $572 \mathrm{ng} \mathrm{L}^{-1}$, respectively. Although it was not referred explicitly to whom with the larger aqueous solubility, syn-DP was generally richer in aqueous body than matched sediment in the previous studies (Sverko et al., 2011; Xian et al., 2011), implying higher aqueous solubility of syn-DP than anti-DP. Likely, when DP isomers were transferred from blood to brain, the more aqueous components in blood might cause more retention of syn-DP, resulting in relatively more transfer residual of anti-DP in brain tissues. Therefore, the theory of similarity and intermiscibility might explain more in selective bioaccumulation of DP isomers in the process of blood-brain distribution compared with the structural-dependent theory.

\subsection{Dechlorinated products of DP}

To date, the dechlorination products of DP (including syn- $\mathrm{Cl}_{11}$ $\mathrm{DP}$ and anti-Cl $\mathrm{Cl}_{11}$-DP) have been found in some organism, such as in birds (Mo et al., 2013) and bird eggs (Guerra et al., 2011), fish (Peng et al., 2012; Zhang et al., 2011a,b), frog (Li et al., 2014) and chicken (Zheng et al., 2014). However, data gap still existed on the origin of these compounds in biota.

Liver was considered to be a main metabolic organ in organism, if any dechlorination process occurred, a higher ratio of monodechlorinated products against DP shall be observed in liver compared with other tissues. In this study, the mean values of anti$\mathrm{Cl}_{11}$-DP/anti-DP and syn- $\mathrm{Cl}_{11}$-DP/syn-DP in liver, muscle, blood and fat are listed in Table 3. The mean ratio in liver showed the lowest in the four tissues, suggesting the less likeliness that the anti- $\mathrm{Cl}_{11}-\mathrm{DP} /$ syn- $\mathrm{Cl}_{11}$-DP mainly transformed from the parent compound in vivo. Previous studies also found the animal liver tissues had low monodechlorination ability in Chinese sturgeon (Peng et al., 2012), rainbow trout (Tomy et al., 2008) and mud carp (Zhang et al., 2011a,b). Considering the larger molecular weight and Kow of DP, this lowest value in liver may be ascribed to the relatively higher liver sequestration capability to DP compared with its monodechlorination products, rather than liver metabolic capability to parent DP.

\section{Conclusions}

DP and its analogues were generally detected in several tissues of domestic ducks collected from e-waste recycling sites in Taizhou, China, indicating DP pollution in this study area. The tissue distribution of DP might be not only related to tissue lipid pools, but also other mechanisms such as the liver sequestration and blood-brain barrier, which might affect its partitioning within the body. The enhanced efficiency of maternal transfer was found for Dec 602 . The stereo-selective accumulation occurred in the duck tissues, indicating the different exposure risk of DP isomers to organs. The monodechlorinated products of DP in duck tissues are likely to be originated from the environment rather than transformed from the parent compound in vivo.

\section{Acknowledgments}

Financial supports from the National Natural Science Foundation of China (21177152 and 21477157) and the State Key Laboratory 


\section{of Environmental Chemistry and Ecotoxicology, Research Center for Eco-Environmental Sciences, Chinese Academy of Sciences (no. KF- 2013-01) are gratefully acknowledged.}

\section{References}

Barrier, B.B., Peterson, D.R., 2010. Blood-brain Barrier. Cancer Symptom Science: Measurement, Mechanisms, and Management, p. 9.

Ben, Y.J., Li, X.H., Yang, Y.L., Li, L., Di, J.P., Wang, W.Y., et al., 2013. Dechlorane Plus and its dechlorinated analogs from an e-waste recycling center in maternal serum and breast milk of women in Wenling, China. Environ. Pollut. 173, 176-181.

Ben, Y.J., Li, X.H., Yang, Y.L., Li, L., Zheng, M.Y., Wang, W.Y., et al., 2014. Placental transfer of dechlorane plus in mother-infant pairs in an e-waste recycling area (Wenling, China). Environ. Sci. Technol. 48, 5187-5193.

Chen, S.J., Tian, M., Wang, J., Shi, T., Luo, Y., Luo, X.J., et al., 2011. Dechlorane Plus (DP) in air and plants at an electronic waste (e-waste) site in South China. Environ. Pollut. 159, 1290-1296.

Commission, S.E., 2011. The European Commission Report on Potential Alternatives to Deca-BDE (accessed January 16, 2011). http://ecb.jrc.ec.europa.eu/ documents/Existing-Chemicals/Review_on_production_process_of_decaBDE.

Gauthier, L.T., Letcher, R.J., 2009. Isomers of dechlorane Plus flame retardant in the eggs of herring gulls (Larus argentatus) from the Laurentian Great Lakes of North America: temporal changes and spatial distribution. Chemosphere 75 115-120.

Guerra, P., Fernie, K., Jimenez, B., Pacepavicius, G., Shen, L., Reiner, E., et al., 2011 Dechlorane plus and related compounds in peregrine falcon (Falco peregrinus) eggs from Canada and Spain. Environ. Sci. Technol. 45, 1284-1290.

Jia, H.L., Sun, Y.Q., Liu, X.J., Yang, M., Wang, D.G., Qi, H., et al., 2011. Concentration and bioaccumulation of dechlorane compounds in coastal environment of northern China. Environ. Sci. Technol. 45, 2613-2618.

Li, L., Wang, W., Lv, Q., Ben, Y., Li, X., 2014. Bioavailability and tissue distribution of dechloranes in wild frogs (Rana limnocharis) from an e-waste recycling area in Southeast China. J. Environ. Sci. 26, 636-642.

Luo, X.J., Liu, J., Luo, Y., Zhang, X.L., Wu, J.P., Lin, Z., et al., 2009. Polybrominated diphenyl ethers (PBDEs) in free-range domestic fowl from an e-waste recycling site in South China: levels, profile and human dietary exposure. Environ. Int. 35, $253-258$.

Mo, L., Wu, J.P., Luo, X.J., Sun, Y.X., Zheng, X.B., Zhang, Q., et al., 2013. Dechlorane Plus flame retardant in kingfishers (Alcedo atthis) from an electronic waste recycling site and a reference site, South China: influence of residue levels on the isomeric composition. Environ. Pollut. 174, 57-62.

Moller, A., Xie, Z.Y., Sturm, R., Ebinghaus, R., 2010. Large-scale distribution of dechlorane plus in air and seawater from the Arctic to Antarctica. Environ. Sci. Technol. 44, 8977-8982.

Peng, H., Zhang, K., Wan, Y., Hu, J., 2012. Tissue distribution, maternal transfer, an age-related accumulation of dechloranes in Chinese sturgeon. Environ. Sci. Technol. 46, 9907-9913.

Qiu, X. Hites, R.A., 2008. Dechlorane plus and other flame retardants in tree bark from the Northeastern United States. Environ. Sci. Technol. 42, 31-36.

Ren, G., Yu, Z., Ma, S., Li, H., Peng, P., Sheng, G., et al., 2009. Determination of dechlorane plus in serum from electronics dismantling workers in South China. Environ. Sci. Technol. 43, 9453-9457.

Russell, R.W., Gobas, F.A.P.C., Haffner, G.D., 1999. Maternal transfer and in ovo exposure of organochlorines in oviparous organisms: a model and field verification. Environ. Sci. Technol. 33, 416-420.

Salamova, A., Hites, R.A., 2011. Dechlorane plus in the atmosphere and Precipitation near the Great Lakes. Environ. Sci. Technol. 45, 9924-9930.

Shen, L., Reiner, E.J., MacPherson, K.A., Kolic, T.M., Sverko, E., Helm, P.A., et al., 2009 Identification and screening analysis of halogenated Norbornene flame retardants in the Laurentian Great Lakes: dechloranes 602, 603, and 604. Environ. Sci. Technol. 44, 760-766.

Shen, L., Reiner, E.J., Helm, P.A., Marvin, C.H., Hill, B., Zhang, X.M., et al., 2011. Historic trends of dechloranes 602, 603, 604, dechlorane plus and other Norbornene derivatives and their bioaccumulation potential in Lake Ontario. Environ. Sci. Technol. 45, 3333-3340.

Siddique, S., Xian, Q.M., Abdelouahab, N., Takser, L., Phillips, S.P., Feng, Y.L., et al., 2012. Levels of dechlorane plus and polybrominated diphenylethers in human milk in two Canadian cities. Environ. Int. 39, 50-55.

Suhring, R., Freese, M., Schneider, M., Schubert, S., Pohlmann, J.D., Alaee, M., et al., 2015. Maternal transfer of emerging brominated and chlorinated flame re tardants in European eels. Sci. Total Environ. 530-531, 209-218.

Sun, Y., Luo, X., Wu, J., Mo, L., Chen, S., Zhang, O., et al., 2012. Species- and tissuespecific accumulation of dechlorane Plus in three terrestrial passerine birc species from the Pearl River Delta, South China. Chemosphere 89, 445-451.

Sverko, E., Tomy, G.T., Marvin, C.H., Zaruk, D., Reiner, E., Helm, P.A., et al., 2008. Dechlorane plus levels in sediment of the lower Great Lakes. Environ. Sci.
Technol. 42, 361-366.

Sverko, E., Reiner, E.J., Tomy, G.T., McCrindle, R., Shen, L., Arsenault, G. et al., 2010 Compounds structurally related to dechlorane plus in sediment and biota from Lake Ontario (Canada). Environ. Sci. Technol. 44, 574-579.

Sverko, E., Tomy, G.T., Reiner, E.J., Li, Y.-F., McCarry, B.E., Arnot, J.A., et al., 2011. Dechlorane plus and related compounds in the environment: a review. Environ. Sci. Technol. 45, 5088-5098.

Tomy, G.T., Pleskach, K., Ismail, N., Whittle, D.M., Helm, P.A., Sverko, E., et al., 2007. Isomers of dechlorane plus in Lake winnipeg and Lake Ontario food webs. Environ. Sci. Technol. 41, 2249-2254.

Tomy, G.T., Thomas, C.R., Zidane, T.M., Murison, K.E., Pleskach, K., Hare, J., et al., 2008. Examination of isomer specific bioaccumulation parameters and potential in vivo hepatic metabolites of syn- and anti-Dechlorane Plus isomers in juvenile rainbow trout (Oncorhynchus mykiss). Environ. Sci. Technol. 42, 5562-5567.

Voorspoels, S., Covaci, A., Lepom, P., Jaspers, V.L., Schepens, P., 2006. Levels and distribution of polybrominated diphenyl ethers in various tissues of birds of prey. Environ. Pollut. 144, 218-227.

Wan, Y., Hu, J.Y., An, W., Zhang, Z.B., An, L.H., Hattori, T., et al., 2006. Congenerspecific tissue distribution and hepatic sequestration of PCDD/Fs in wild herring gulls from Bohai Bay, North China: comparison to coplanar PCBs. Environ. Sci. Technol. 40, 1462-1468.

Wang, B., Iino, F., Huang, J., Lu, Y., Yu, G., Morita, M., 2010a. Dechlorane Plus pollution and inventory in soil of Huai'an City, China. Chemosphere 80, 1285-1290.

Wang, D.-G., Yang, M., Qi, H., Sverko, E., Ma, W.-L., Li, Y.-F., et al., 2010b. An Asiaspecific source of dechlorane plus: concentration, isomer profiles, and other related compounds. Environ. Sci. Technol. 44, 6608-6613.

Wang, D., Shelver, W.L., Atkinson, S., Mellish, J.A., Li, Q.X., 2010c. Tissue distribution of polychlorinated biphenyls and organochlorine pesticides and potential toxicity to Alaskan northern fur seals assessed using PCBs congener specific mode of action schemes. Arch. Environ. Contam. Toxicol. 58, 478-488.

Wu, J.-P., Luo, X.-J., Zhang, Y., Chen, S.-J., Mai, B.-X., Guan, Y.-T., et al., 2009. Residues of polybrominated diphenyl ethers in frogs (Rana limnocharis) from a contaminated site, South China: tissue distribution, biomagnification, and maternal transfer. Environ. Sci. Technol. 43, 5212-5217.

Wu, J.P., Zhang, Y., Luo, X.J., Wang, J., Chen, S.J., Guan, Y.T., et al., 2010. Isomerspecific bioaccumulation and trophic transfer of dechlorane plus in the Freshwater food web from a highly contaminated site, South China. Environ. Sci. Technol. 44, 606-611.

Wu, J.P., She, Y.Z. Zhang Y. Peng Y Mo, L, Luo, X. et al, 2013. Sex-dependent accumulation and maternal transfer of dechlorane Plus flame retardant in fish from an electronic waste recycling site in South China. Environ. Pollut. 177, 150-155.

Xian, Q.M., Siddique, S., Li, T., Feng, Y.L., Takser, L., Zhu, J.P., 2011. Sources and environmental behavior of dechlorane plus - a review. Environ. Int. 37, 1273-1284.

Yang, R.Q. Wei, H., Guo, J.H., McLeod, C., Li, A., Sturchio, N.C., 2011a. Historically and currently used dechloranes in the sediments of the Great Lakes. Environ. Sci. Technol. 45, 5156-5163.

Yang, Z.Z., Li, Y.F., Fu, S., Zhao, X.R., 2011b. Special distribution of polybrominated diphenyl ethers in brain tissues of free-range domestic hens and ducks from a village near an electronic waste recycling site in South China. Bull. Environ. Contam. Toxicol. 86, 283-288.

Yu, Z., Lu, S., Gao, S., Wang, J. Li, H., Zeng, X., et al., 2010. Levels and isomer profiles of dechlorane Plus in the surface soils from e-waste recycling areas and industrial areas in South China. Environ. Pollut. 158, 2920-2925.

Yu, Z.Q., Liao, R.E., Li, H.R., Mo, L.G., Zeng, X.Y., Sheng, G.Y., et al., 2011. Particlebound dechlorane Plus and polybrominated diphenyl ethers in ambient air around Shanghai, China. Environ. Pollut. 159, 2982-2988.

Zhang, X.L., Luo, X.J., Liu, H.Y., Yu, L.H., Chen, S.J., Mai, B.X., 2011a. Bioaccumulation of several brominated flame retardants and dechlorane plus in waterbirds from an e-waste recycling region in South China: associated with trophic level and diet sources. Environ. Sci. Technol. 45, 400-405.

Zhang, Y., Wu, J.P., Luo, X.J., Wang, J., Chen, S.J., Mai, B.X., 2011b. Tissue distribution of dechlorane Plus and its dechlorinated analogs in contaminated fish: high affinity to the brain for anti-DP. Environ. Pollut. 159, 3647-3652.

Zheng, J., Wang, J., Luo, X.-J., Tian, M., He, L.-Y., Yuan, J.-G., et al., 2010. Dechlorane plus in human hair from an e-waste recycling area in South China: comparison with dust. Environ. Sci. Technol. 44, 9298-9303.

Zheng, X.B., Wu, J.P., Luo, X.J., Zeng, Y.H., She, Y.Z., Mai, B.X., 2012. Halogenated flame retardants in home-produced eggs from an electronic waste recycling region in South China: levels, composition profiles, and human dietary exposure assessment. Environ. Int. 45, 122-128.

Zheng, X.B., Luo, X.J., Zeng, Y.H., Wu, J.P., Mai, B.X., 2014. Sources, gastrointestinal absorption and stereo-selective and tissue-specific accumulation of dechlorane Plus (DP) in chicken. Chemosphere 114, 241-246. 